\title{
The therapeutic target of estrogen receptor-alpha36 in estrogen-dependent tumors
}

\author{
Yu Gu${ }^{1 \dagger}$, Tianxiang Chen ${ }^{2 \dagger}$, Elena López ${ }^{3}$, Weizhu Wu ${ }^{4}$, Xiangdong Wang ${ }^{5^{*}}$, Jiang Cao ${ }^{6 *}$ and Lisong Teng ${ }^{1 *}$
}

\begin{abstract}
Estrogen receptor-alpha36 (ER-a36) is a new isoform of estrogen receptors without transcriptional activation domains of the classical ER-a(ER - a66). ER-a36 is mainly located in cytoplasm and plasma membrane. ER-a36 mediates non-genomic signaling and is involved in genomic signaling of other ERs. Recently ER-a36 is found to play a critical role in the development of estrogen-dependent cancers and endocrine resistance of breast cancer. The present article overviews and updates the biological nature and function of ER-a36, potential interaction of ER-a36 with other estrogen receptors and growth factor receptors, intracellular signaling pathways, potential mechanism by which ER-a36 may play an important role in the development of tumor resistance to endocrine therapies.
\end{abstract}

Keywords: Estrogen receptor, ER-alpha36, Non-genomic signaling, Breast cancer, Hormone-dependent cancer, Endocrine therapy resistance

\section{Introduction}

Estrogens, mainly $17 \beta$-estradiol (E2), regulate growth, differentiation, and homeostasis of eukaryotic cells. Notably, it is associated with a higher risk of the development of breast and endometrial cancer [1]. Two forms of estrogen receptors (ERs), ER- $\alpha$ and ER- $\beta$, were respectively discovered in 1962 [2] and in 1996 [3], and suggested to dominate the regulation of various biological functions. A number of ER variants were identified since then and found to coexist with these wild-type ERs, including ER- $\alpha 36$, ER- $\alpha 46$, and ER- $\beta 2-5$ [4-6]. Of them ER- $\alpha 36$ is a $36-k D a$ novel isoform of ER- $\alpha 66$ identified and cloned by Wang et al., in 2005 [6]. It is considered as a new and important factor to understand the pleiotropic effects of estrogen, even in organs without ER- $\alpha 66$. Human ER- $\alpha 36$ differs from hER- $\alpha 66$ by lack of both transcriptional activation domains (AF-1 and AF-2), but it retains partial dimerization, DNAbinding and ligand-binding domains. Initially ER- $\alpha 36$ was

\footnotetext{
*Correspondence: xiangdong.wang@clintransmed.org; caoj@zju.edu.cn; Isteng@zju.edu.cn

${ }^{\dagger}$ Equal contributors

${ }^{5}$ Department of Respiratory Medicine, The First Hospital of Wenzhou Medical University, Wenzhou, China

${ }^{6}$ Clinical Research Center, The 2nd Affiliated Hospital, School of Medicine, Zhejiang University, Hangzhou, Zhejiang Province, China

'Department of Surgical Oncology, The 1st Affiliated Hospital, School of Medicine, Zhejiang University, 79, Qingchun Road, Hangzhou 310003

Zhejiang Province, China

Full list of author information is available at the end of the article
}

proposed to be a dominant-negative effector in estrogenstimulated activation of estrogen-responsive genes through hER- $\alpha 66$ [6] and crucial in estrogen-stimulated membrane responses [7].

The intracellular location is important for molecular function of ERs. With different intracellular expression on nucleus, cytoplasmic or membrane, estrogens can function through ERs differently [8]. The genomic action of ER is considered as nuclear-initiated steroid signaling, and the non-genomic action of ER as membrane-initiated steroid signaling [9-11]. Non-genomic pathway regulates more genes than just genomic action of ER alone. It involves in different cellular processes like proliferation, survival, apoptosis and differentiated functions in diverse cell-types. ER- $\alpha 36$ is found localized in both plasma membrane and cytoplasm. Thus, it may be related with both genomic and non-genomic signaling network.

The activation of ERs was found to be associated with carcinogenesis, progression, and endocrine resistance of steroid-responsive cancers [12]. The expression of ER- $\alpha 36$ was correlated with clinical phenotypes and endocrine therapy responses of patients with various cancers, particularly breast cancer. It was proposed that ER- $\alpha 36$ as a novel tumor-associated ER isoform could act as a potential biomarker for diagnosis and treatment of estrogendependent carcinoma $[4,6]$. Signaling pathways activated by estrogen and anti-estrogen through ER- $\alpha 36$ may help 
us understand why human breast cancers are resistant to or worsened by anti-estrogen therapy. The present review surveys updated knowledge on ER- $\alpha 36$ biology, non-nuclear receptor functions, its role in estrogendependent tumors and its action in human breast cancer diagnosis and treatment, especially emphasize on endocrine resistance.

\section{The biology of ER-a36}

The non-coding novel exon of ER- $\alpha 36$ from the first intron of ER- $\alpha 66$ gene is designated as 'exon1', to distinguish it from the original exon1 in ER- $\alpha 66$ gene. 'Exon1' is directly spliced into exon2 of ER- $\alpha 66$ gene. ER- $\alpha 36$ continues from exon 2 to exon 6 of ER- $\alpha 66$ gene with $100 \%$ match. It has a unique C-terminal 27 amino acid domain that replaces the last 138 amino acids encoded by exon 7 and 8 of the ER- $\alpha 66$ gene [6] (Figure 1A). ER- $\alpha 66$ and ER- $\beta$ are composed of three independent but interacting functional domains [13,14], among which the A/B domain contains AF-1 and is involved in interactions with co-activators and transcriptional activation of target genes [15]. The DNA binding domain, or $\mathrm{C}$ domain allows both receptors to bind to similar target sites. The $\mathrm{D}$ domain or hinge region contains nuclear localization signal. The $\mathrm{E} / \mathrm{F}$ region is a ligand-binding domain that mediates ligand binding, receptor dimerization, nuclear localization and liganddependent transactivation (AF-2) [8]. Compared to ER- $\alpha 66$,
ER- $\alpha 36$ lacks two transcriptional activation domains AF-1 and AF-2 while retains the DNA-binding domain as well as partial dimerization, ligand-binding domains (Figure 1B) [6]. ER- $\alpha 36$ elicits membrane-initiated signaling in response to E2- $\alpha, E 2-\beta, E 3$, and E4 as well as tamoxifen. It indicates that ER- $\alpha 36$ possesses a broader ligand-binding spectrum than ER- $\alpha 66$ and it may act as a potential mediator of mitogenic estrogen signaling [7].

Wang et al. isolated nuclear, plasma membrane and cytosolic fractions from ER- $\alpha 36$-expressing HEK-293 cells and found that $50 \%$ of ER- $\alpha 36$ fractionates with plasma membrane, $40 \%$ with cytosol and $10 \%$ with nuclei [7]. The variation of ER- $\alpha 36$ locations on plasma membrane or cytoplasm was noted to be associated with different types of cancer cells including breast [16], endometrial [17], colorectal [18], gastric [19] and hepatic cancers [20]. ER- $\alpha 36$ is also expressed in the cell membrane of normal hamster ovary cells [21]. Furthermore, ER- $\alpha 36$ is modified by post-translational palmitoylation in the ligand-binding domain and it has three potential myristoylation sites that may contribute to its membrane localization $[6,22]$ (Figure 2).

\section{The non-nuclear receptor functions of ER-a36}

The classical mechanism of ER action involves the binding of estrogen to nuclear receptors. After that the receptors dissociate from Hsps, dimerize and bind to specific

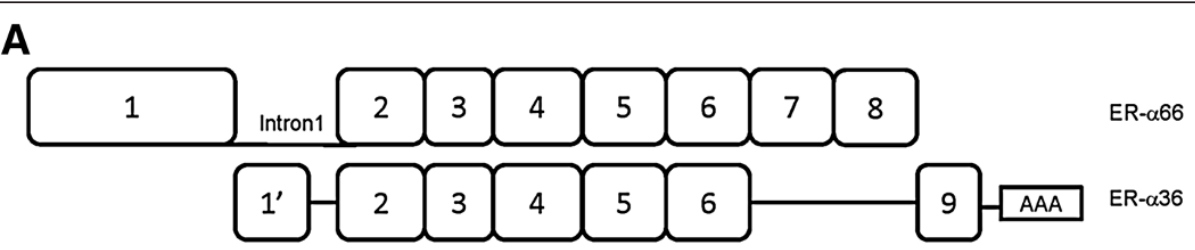

B

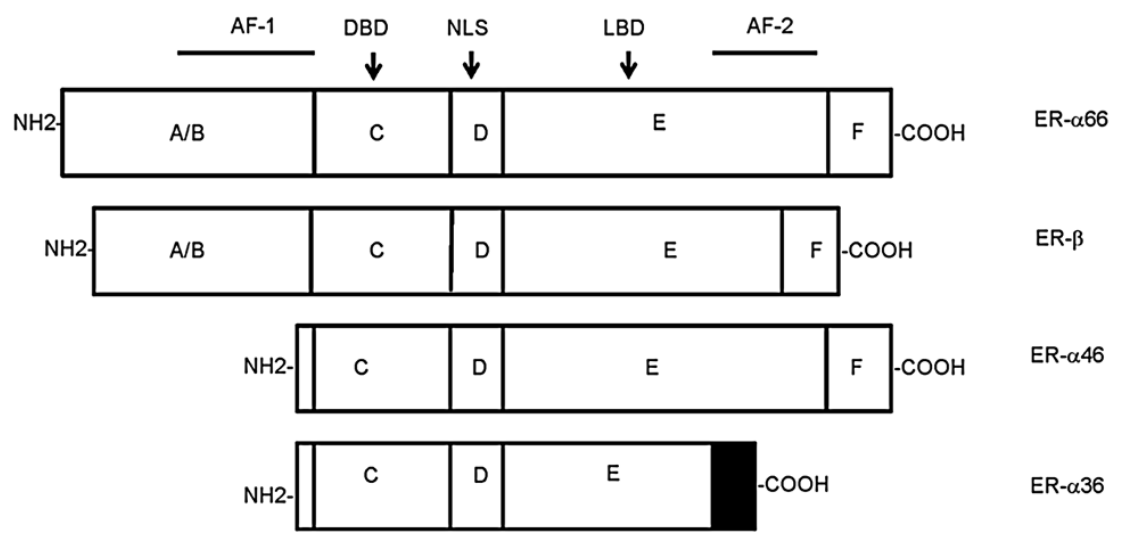

Figure 1 Biological structure of ER-a36. (A) The exon of ER-a36 from intron1 of ER-a66 gene is designated as 1'. The extra exon of ER-a36 gene that is beyond 8 exons of ER-a66 gene is numbered as 9 . ER-a36 has a unique 27 amino acid domain at C-terminus. Deletions are indicated by a single line. (B) Protein structure of ER isoforms includes A/B domain contains transcriptional-activation function AF-1, C domain represents DNA-binding-domain (DBD), D domain contains nuclear localization signal (NLS), and E domain corresponds to ligand binding domain (LBD) and transcriptional-activation function AF-2. ER-a36 lacks AF-1 and AF-2. The last 27 amino acids of ER-a36 are indicated by a shaded box. 


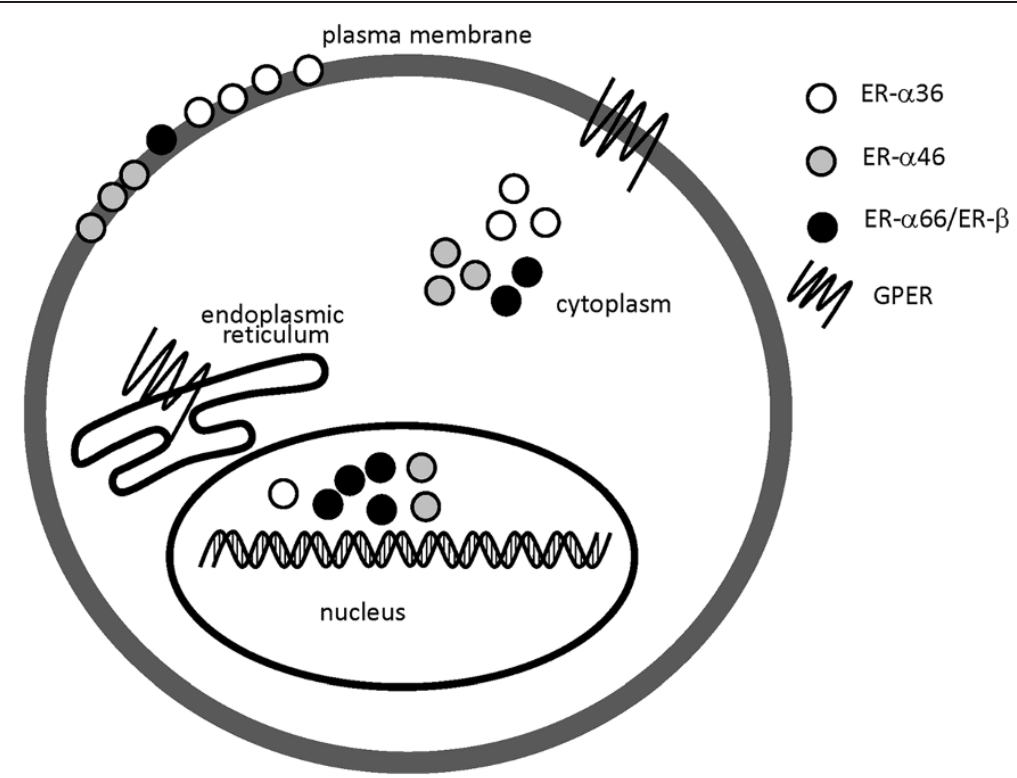

Figure 2 Diagram of locations of different ERs. ER-a36 is mainly localized in plasma membrane and cytoplasm, little is found in nucleus. Classical ERs like ER-a66 and ER- $\beta$ are mainly expressed in nucleus and cytoplasm with little in plasma membrane. As to other ERs (e.g. ER-a46 and GPER), the cellular localization usually depends on cell types.

response elements known as estrogen response elements which located in the promoters of target genes [23]. ERs can mediate the transcription through protein-protein interactions with other DNA-binding transcription factors in the nucleus. In addition, ligand-independent pathways have been described. Growth factor signaling can trigger ERs through the activation of kinases and/or be associated co-regulators in the absence of ligand [24] (Figure 3).

E2 was reported to bind to a cell surface receptor and stimulate a rapid generation of cAMP [25], meanwhile the plasma membrane-localized ER was also proposed to transduce membrane-initiated estrogen signaling. Estrogens can rapidly function through the non-genomic mechanisms independent on the activation of RNA and protein synthesis. As a non-nuclear ER, ER- $\alpha 36$ not only inhibits the genomic estrogen signaling of nuclear ER, but also mediates the non-genomic estrogen signaling.

\section{ER-a36 and other estrogen receptors}

ER- $\alpha 36$ lacks transcription activation domains of ER- $\alpha 66$ and detectable levels of intrinsic transcriptional activity with or without the presence of E2 [7]. The presence of ER- $\alpha 36$ could inhibit E2 $\beta$-dependent and -independent transactivation functions mediated by AF-1 or AF-2 domains of ER- $\alpha 66$ and ER- $\beta$ (Figure 3). ER- $\alpha 36$ also effectively competes with ER- $\alpha 66$ and ER- $\beta$ for the DNA-binding elements in estrogen-responsive genes [7]. On the other hand, transient co-transfection experiments demonstrated that ER- $\alpha 66$ suppressed ER- $\alpha 36$ promoter activity in an estrogen-independent manner, the suppression could be released by ER- $\alpha 36$ itself [26]. Wilm's tumor1, as a dual transcription factor, was found to regulate the promoter activity of ER- $\alpha 66$ and ER- $\alpha 36$ oppositely in breast cancer cells [27]. All above may explain the phenomenon that ER- $\alpha 36$ expression appears to be associated with decreasing ER- $\alpha 66$ expression in many kinds of cancers [16].

A new membrane-bound estrogen receptor GPER was identified with homology to the G-protein-coupled receptor superfamily. In addition, GPER was suggested to be associated with classical estrogen receptor expression in breast cancer [28-30]. Kang et al. found that G1, a GPERspecific agonist, could stimulate ER- $\alpha 36$ to regulate the non-genomic signaling pathway through p-ERK1/2 rather than GPER [31]. GPER was also found to be necessary for the stimulated expression of ER- $\alpha 36$ which triggered by E2 [32]. Current knowledge suggests estrogen may activate GPER to induce ER- $\alpha 36$ expression (as shown in Figure 4).

\section{ER-a36 and growth factor receptors}

Both ER- $\alpha 36$ and EGFR are mainly localized on plasma membrane, they have a positive correlation with each other in breast cancer and endometrial cancer [33]. EGFR signaling might induce the promoter activity of ER- $\alpha 36$ gene via an Ap-1 binding site. ER- $\alpha 36$ was found to be necessary for both EGFR membrane localization and E2-mediated stimulation of EGFR expression in TCam-2 cells. It stabilized the steady state protein levels of EGFR in breast cancer [32,34]. After E2- $\beta$ treatment of breast cancer cells, ER- $\alpha 36$ gradually dissociates from EGFR and meanwhile associates with Src and Shc. This process suggests that ER- $\alpha 36$ might dynamically change its partners 


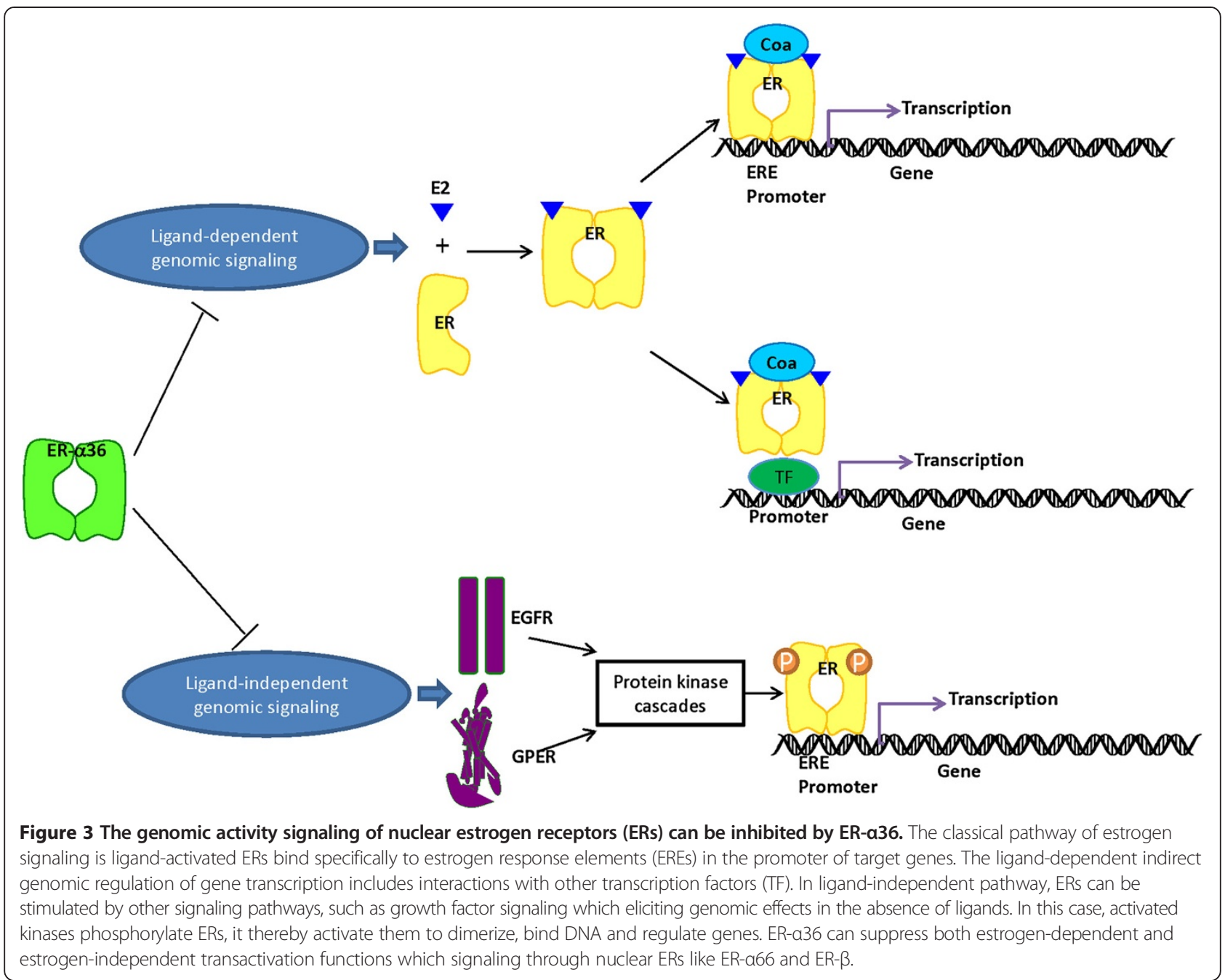

within EGFR/Src/Shc complex during estrogen signaling [34]. Interestingly, low concentration of estrogen or certain anti-estrogens like tamoxifen are shown to stimulate cell proliferation by eliciting mitogenic signaling pathway, while high concentration to inhibit cell growth $[35,36]$. Such paradoxical effect was believed to be regulated by ER- $\alpha 36$ in ER-negative breast cancer cells [34,35]. Furthermore, ER$\alpha 36$ is also proposed to regulate the phosphorylation of both Src/EGFR and MAPK/ERK during mitogenic signaling and to activate Cyclin D1 promoter activity through Src/EGFR/STAT5 pathway (Figure 4). EGF treatment was discovered to increase ERK1/2 phosphorylation in ER- $\alpha 36$ expressing Hec1A cells, but not in ER- $\alpha 36$ knockdown cells. This finding tells us ER- $\alpha 36-E G F R$ complex mediated MAPK/ERK pathway activation may be critical in the nongenomic estrogen signaling [17]. Recently we found, for the first time, that ER- $\alpha 36$ up-regulated EGFR expression, while down-regulated ER- $\alpha 66$ expression in MCF7 cells. Our study provided a potential mechanism for the growth switch of breast tumors after acquired tamoxifen resistance [37].
Human epidermal growth factor receptor 2 (HER2), as member of EGFR superfamily, was also significantly correlated with ER- $\alpha 36$ expression in patients with breast cancer like EGFR [38]. In vitro study showed HER2 and ER- $\alpha 36$ was present in the same protein complex in ER-negative breast cancer SK-BR-3 cells. It was noted that HER2 signaling activated ER- $\alpha 36$ promoter activity through an AP-1dependent signaling pathway and ER- $\alpha 36$ activated HER2 transcription [39]. Therefore, The interplay between growth factor receptors and ER- $\alpha 36$ may play an important role in development and progression of subsets of cancer with highly expression of ER- $\alpha 36$.

\section{ER-a36 and downstream kinases Mitogen-activated protein kinases}

The signaling cascades in the MAPK/ERK pathways are proposed as major intracellular communication in breast, prostate and colon cancers [40]. Wang et al. reported that ERK1/2 phosphorylation of ER- $\alpha 36$ transfected HEK293cells was increased comparing to control cells with the 


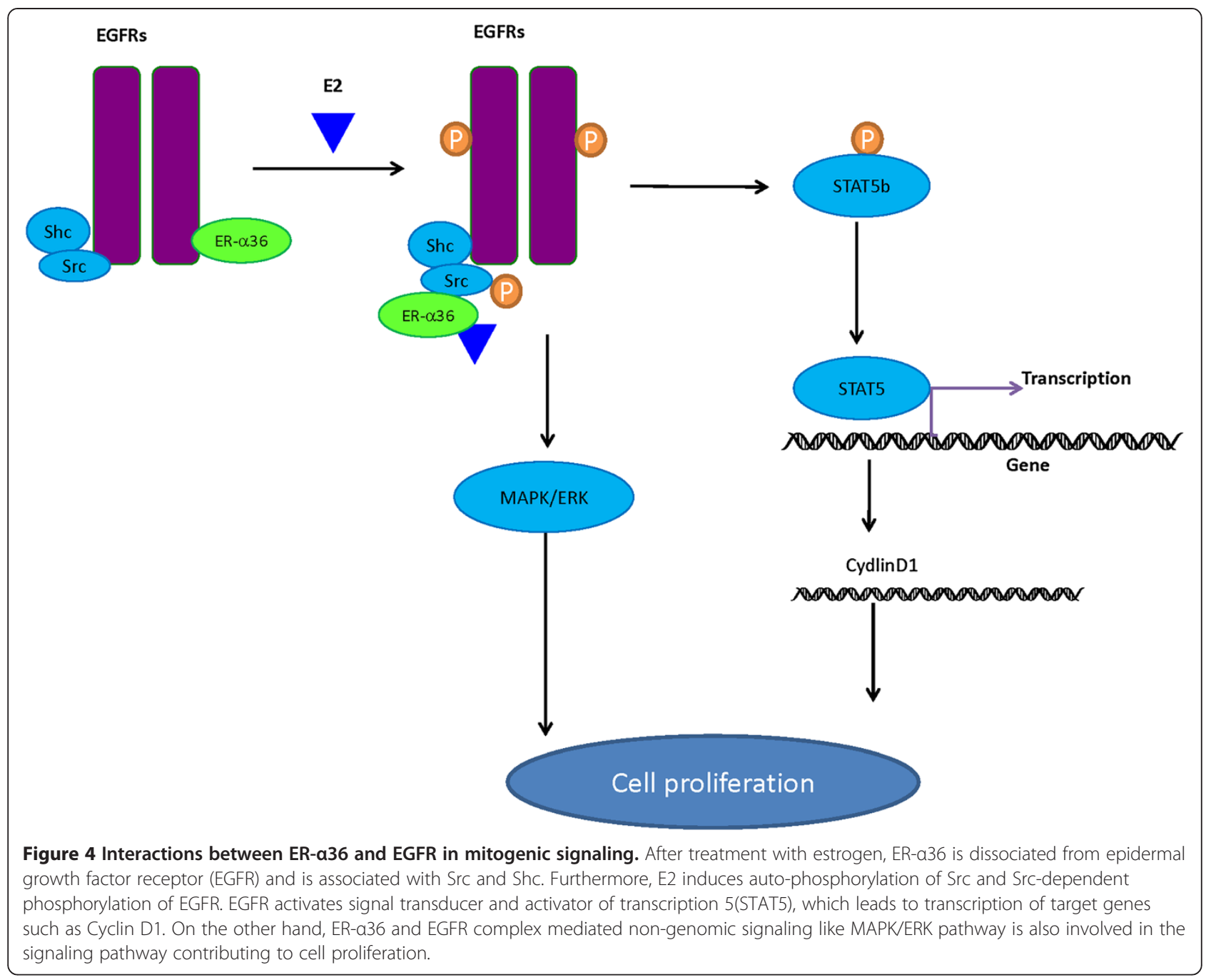

E2 $\beta$ treatments or not. Similar finding was introduced after cells treating with E2 $\beta$-BSA which was a membraneimpermeable form of E2- $\beta$ [7]. It indicates that E2-mediated ERK1/2 activation might be initiated by a membrane-initiated estrogen-signaling pathway via ER- $\alpha 36$. Importantly, such mechanism was also proven in breast and endometrial cancer cells $[31,34,36,41,42]$. Those findings demonstrate the involvement of MAPK/ERK pathway in estrogen-related signal of hormonal dependent cancer cells by a combination of ER- $\alpha 36$. Besides, PKC was evidenced to rapidly enhance phosphorylation of proliferation promoting proteins by activation of ERK1/2 [43]. Tong et al. found that ER- $\alpha 36$ mediated E2-induced activation of MAPK/ERK pathway also via $\mathrm{PKC}$ in endometrial cancer cells [44]. Furthermore, the stimulated PKC of ER- $\alpha 36$ expressing breast cancer cells contributed to increased proliferation in response to E2 [45].

Only with the presence of ER- $\alpha 36$ but not ER- $\alpha 66$, the treatment of estradiol and anti-estrogenic agents led to rapid activation of p-ERK $1 / 2$ and substantial increase of cell migration and invasiveness in inflammatory breast cancer [42]. Both basal and ligand-induced migration and invasiveness of ER- $\alpha 36$ expressing breast cancer cells were drastically reduced after treatment of MEK inhibitor U0126. These results implicated that phosphorylation of ERK1/2 by MEK might be involved in the cell motility and invasiveness. It was also evidenced by the up-regulation of p-ERK $1 / 2$ in patients with inflammatory breast cancer [42]. Collectively it is possible that ER- $\alpha 36$ may promote proliferation and invasion of cancer cells via MAPK/ERK signaling pathway.

c-Jun N-terminal Kinases (JNKs), as another principal members of MAPK family, regulate cell proliferation, differentiation and migration [46]. Our laboratory revealed that less activation of JNKs and major proportion of cells arrested at the G2/M phase in the absence of ER- $\alpha 36$ were seen after treatment of paclitaxel [47], which induces cell cycle arrest at the G2/M phase and result in endoreduplication [48]. Our results suggest that ER- $\alpha 36$ antagonizes the effect of paclitaxel via activation of JNKs pathway (Figure 5). 


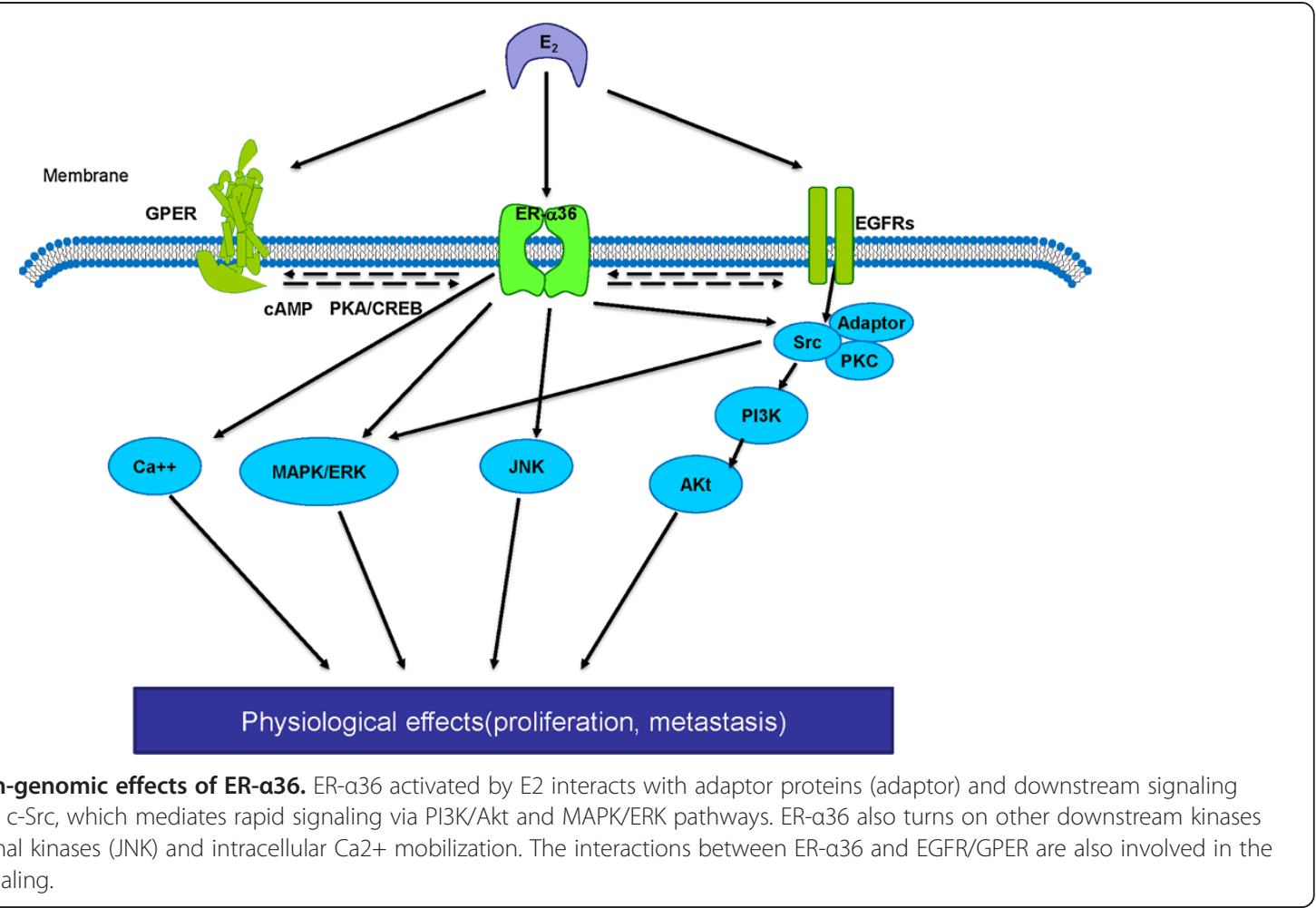

\section{The serine/threonine kinase}

The serine/threonine kinase (Akt), also named as protein kinase $\mathrm{B}$, is important in cell proliferation and survival by inhibition of apoptosis [49]. Treatments with testosterone, E2, or tamoxifen induce rapid phosphorylation of Akt in Hec1A cells can be abrogated in the absence of ER- $\alpha 36$ [41]. Tamoxifen induces Akt phosphorylation in ER- $\alpha 36$ high expressing MCF-7cells, while pre-treatment with PI3K inhibitor abrogates Akt phosphorylation stimulated by E2 or tamoxifen. It indicates that ER- $\alpha 36$ may mediate multi-ligands-induced Akt phosphorylation mainly through PI3K pathway [36]. The PI3K/Akt signaling pathway in an ER- $\alpha 36$-dependent way could be activated by the inhibition of Caveolin-1, a major protein component of Caveolae and a potential tumor suppressor [50-52] (Figure 5). In addition, $\mathrm{E} 2$ fail to induce intracellular $\mathrm{Ca}^{+}$mobilization in ER- $\alpha 36$ negative breast cancer cells. It suggests that ER- $\alpha 36$ is involved in estrogen-induced intracellular $\mathrm{Ca}_{2}^{+}$response, although the exact mechanisms by which ER- $\alpha 36$ influences $\mathrm{Ca}^{+}$mobilization remain unclear [31].

\section{ER-a36 and estrogen-dependent tumors Breast cancer}

General characteristics of ER- $\alpha 36$ in breast cancer ER- $\alpha 36$ is both expressed on plasma membrane and in cytoplasm in different breast cancer cell lines, the expression of which is associated with a decrease of ER- $\alpha 66$ in nuclear and/or cytoplasm $[7,16,26]$. However, ER- $\alpha 36$ is not presented in normal mammary epithelial cells like MCF10A [26,39]. The depletion of ER- $\alpha 36$ via siRNA can induce apoptosis of ER negative breast cancer cells [53]. The migration and invasion activity of breast cancer cells can be inhibited in the absence of ER- $\alpha 36$ [47]. ER- $\alpha 36$ rapidly activates $\mathrm{PKC}$ in response to $\mathrm{E} 2$, which leads to promotion of proliferation, protection against apoptosis, and metastasis in breast cancer cells with or without ER- $\alpha$ expression [45]. It suggests that ER- $\alpha 36$ may be a potential therapeutic target for breast tumor growth and metastasis. Different from mRNA expression, only a few translated protein products of ER- $\alpha 66$ variants have been found naturally in breast cancer like ER- $\alpha 36$ [54-57]. ER- $\alpha 36$ was reported to express in a cytoplasmic and plasmamembrane-associated pattern in human tissue of both ER- $\alpha 66$-positive and -negative breast cancer. High expression of ER- $\alpha 36$ is more common in ER- $\alpha 66$-negative tumors, whereas low expression of ER- $\alpha 36$ is more frequently seen in ER- $\alpha 66$-positive tumors [16,33,34,47,58]. In addition, ER- $\alpha 36$ was also found within Golgi apparatus reflecting a putative implication in protein synthesis.

The presence of ER- $\alpha 36$ is not limited to tumor cells of breast cancer patients, but also in endothelial cells, adipocytes, infiltrating lymphocytes and fibroblasts in tumor microenvironment. Moreover, the expression of ER- $\alpha 36$ could be elevated in some cases with strong desmoplasia at the time fibroblasts become reactive [58]. Membrane ER- $\alpha 36$ is correlated with the expression of pro-angiogenic 
miRNA210 in an inverse manner and stratifies miR210related patients survival, this may be understood as a possible anti-angiogenic effect of ER- $\alpha 36$ [58]. Lower expression of ER- $\alpha 36$ is positively correlated with larger size of the tumor, metastases to lymph nodes, advanced severity of disease, and shorter survival of patients with breast cancer $[58,59]$, of which detail information is summarized in Table 1.

Therapeutic significance Anti-estrogens (e.g. tamoxifen, ICI182,780) and aromatase inhibitors (e.g. anastrazole, letrozole) are widely used for the treatment of breast cancer, especially ER-positive breast cancer. Clinical studies demonstrated that approximately $40 \%$ of patients with ER- $\alpha 66$-positive breast cancer had higher expression of ER- $\alpha 36$, and were less sensitive to TAM treatment in comparison with those with ER- $\alpha 66+/ E R-\alpha 36$-tumors [38]. ER-negative breast cancer is less or even nonresponsive to anti-estrogen therapy. However, $45 \%$ patients with ER-/PR + breast cancer and 10\% with ER-/PR-cancer responded to tamoxifen treatment [62]. Gu et al. found that ER- $\alpha 66$-deficient mice retained rapid estrogen-stimulated membrane effects in neurons which were not blocked by ICI 182,780. ER- $\alpha 66-/-$ mice were created by an insertional disruption of the first coding exon of mouse ER- $\alpha 66$ gene. This exon is the one skipped in the generation of transcripts of ER- $\alpha 36$ [63]. Thus, it is possible that ER- $\alpha 36$ may play an important role in the de novo and acquired resistance of breast cancer patients to endocrine therapy.

TAM and its metabolites 4-hydroxytamoxifen (4-OHT) act as antagonists of estrogen by competing with estrogens for the ligand binding domain of ER [64]. It was reported

Table 1 Expression of ER-a36 in cancers

\begin{tabular}{|c|c|c|c|c|}
\hline Tumor type $(*)$ & Study & Kind/num. of analyzed samples & Method $(* *)$ & Potential clinical significant \\
\hline $\mathrm{BC}$ & Lee, et al. [16] & $37 \mathrm{BC}$ tissues & IHCMB & Inverse association with ER-a66 expression \\
\hline $\mathrm{BC}$ & Shi, et al. [38] & 896 BC tissues & $\mathrm{IHC}$ & $\begin{array}{l}\text { ER-a66+/ER-a36Hi tumors are less likely to benefit } \\
\text { from tamoxifen treatment than ER-a66+/ER-a36- } \\
\text { tumors }\end{array}$ \\
\hline $\mathrm{BC}$ & Zheng, et al. [59] & $\begin{array}{l}74 \text { pairs of } B C \text { tissues and matched } \\
\text { normal tissues }\end{array}$ & PCR & $\begin{array}{l}\text { Lower expression in BC tissues than in matched } \\
\text { normal tissues. } \\
\text { Inverse association with local progression/lymph } \\
\text { node metastasis/advanced cancer stage. }\end{array}$ \\
\hline $\mathrm{BC}$ & Zhang, et al. [34] & 12 triple-negative $B C$ tissues & $\mathrm{IHC}$ & Expressed in triple-negative $B C$ \\
\hline $\mathrm{BC}$ & Pelekanou, et al. [58] & $\begin{array}{l}49 \text { triple-negative } B C \text { tissues } \& 34 \\
\text { matched normal samples }\end{array}$ & $\mathrm{IHC}$ & $\begin{array}{l}\text { Highly expressed in triple negative } \mathrm{BC} \text {. } \\
\text { Positive association with overall survival rate }\end{array}$ \\
\hline $\mathrm{BC}$ & Vranic, et al. [33] & $\begin{array}{l}19 \text { pure apocrine carcinomas and } 11 \\
\text { adenoid cystic carcinomas of the } \\
\text { breast }\end{array}$ & $\mathrm{IHC}$ & $\begin{array}{l}\text { Highly expressed in ER-a66 negative apocrine } \\
\text { and adenoid cystic carcinomas of the breast. } \\
\text { Higher expression in the malignant epithelium } \\
\text { than adjacent normal breast tissue }\end{array}$ \\
\hline $\mathrm{BC}$ & Zhang, et al. [35] & $20 \mathrm{BC}$ tissues & $\mathrm{IHC}$ & Inverse association with ER-a66 expression \\
\hline EC & Tu, et al. [17] & 45 EC tissues & $\mathrm{IHC}$ & Positive association with high-stage/high-grade \\
\hline EC & Sun, et al. [60] & $\begin{array}{l}73 \text { EC tissues, } 20 \text { normal endometrial } \\
\text { tissues \& } 9 \text { atypical endometrial } \\
\text { hyperplasia }\end{array}$ & $\mathrm{IHC}$ & $\begin{array}{l}\text { Lower expression in EC tissues than in normal } \\
\text { endometrial tissues and atypical hyperplasia. } \\
\text { Inverse association with disease-free survival rate }\end{array}$ \\
\hline $\mathrm{HCC}$ & Miceli, et al. [20] & $\begin{array}{l}5 \text { normal liver tissues,8 liver cirrhosis } \\
\text { specimens \& } 8 \text { HCC tissues }\end{array}$ & PCR & $\begin{array}{l}\text { Inverse association with ER-a66 expression. } \\
\text { Increase in a stepwise manner from non-tumoural } \\
\text { tissues, cirrhotic tissues to HCC tissues. }\end{array}$ \\
\hline CRC & Jiang, et al. [18] & $\begin{array}{l}35 \text { CRC tissues and their matched } \\
\text { normal tissues }\end{array}$ & PCR & $\begin{array}{l}\text { Lower expression in CRC than matched normal } \\
\text { tissues. } \\
\text { Inverse association with tumour stage/lymph } \\
\text { node metastasis. }\end{array}$ \\
\hline GC & Deng, et al. [61] & 22 GC tissues & $\mathrm{HC}$ & $\begin{array}{l}\text { Higher expression in GC than paired normal } \\
\text { tissues. } \\
\text { Positive association with lymph node metastasis }\end{array}$ \\
\hline GC & Wang, et al. [19] & $\begin{array}{l}45 \text { GC tissues and matched normal } \\
\text { tissues }\end{array}$ & PCR & Lower expression in GC than normal tissues \\
\hline
\end{tabular}


that TAM and 4-OHT failed to block but rather to stimulate the estrogen-triggered ERK1/2 activation through ER- $\alpha 36$ [7]. Later it was found that tamoxifen promoted proliferation of endometrial cancer cells through ER- $\alpha 36$ mediated activation of MAPK/ERK and PI3K/Akt pathways and ER- $\alpha 36$ overexpression led to tamoxifen resistance in MCF-7 cells [36]. Let-7 microRNAs can induce sensitivity of breast cancer to tamoxifen by down-regulation of ERa36 signaling [65]. It is suggested that ER- $\alpha 36$ and its non-genomic activities may be involved in de novo resistance to tamoxifen and even promote the agonist action of tamoxifen [7].

Advanced studies of ER biology have highlighted the intimate cross talk between ER and HER2/growth factor signaling pathways to be a fundamental contributor to the development of TAM therapies resistance. Overexpress of HER2 is found in 25-30\% of breast cancers [66] and it is related to less responsive to tamoxifen treatment [67]. ER- $\alpha 36$ and HER2 are demonstrated to positively regulate the interaction and expression of each other in breast cancer $[38,39]$. It is possible that certain signaling pathway mediated by HER 2 activates ER- $\alpha 36$ expression, which then confers tamoxifen resistance of HER2 over-expressing tumors. On the other hand, our earlier study contributed further knowledge of interactions between ER and EGFR during development of TAM resistance. We established a TAM-resistant breast cancer cell line MCF-7/TAM, of which ER- $\alpha 36$ and EGFR were both overexpressed while ER- $\alpha 66$ was down-regulated comparing to parental MCF7 cells. The silence of ER- $\alpha 36$ expression of MCF-7/TAM cells resulted in decreased expression of EGFR, increased expression of ER- $\alpha 66$, reduced proliferation rate together with decreased in vitro migratory and invasive ability. ER- $\alpha 36$-transfected MCF-7 cells could increase EGFR expression and decrease ER- $\alpha 66$ expression which lead to a decreased sensitivity to TAM. These results indicate, for the first time, a regulatory role of ER- $\alpha 36$ in up-regulation of EGFR expression and down-regulation of ER- $\alpha 66$ expression. This may be a potential mechanism by which the cells acquired TAM resistance [37] (Figure 6B).

Fulvestrant (ICI 182,780), a potent anti-estrogen, inhibits estrogen signaling after it binds to ER- $\alpha 66$ and mediates downstream molecular activities. Through these biological processes, ICI 182,780 impairs ER- $\alpha 66$ dimerization, inhibits nuclear localization of receptor, and accelerates the degradation of ER- $\alpha 66$ protein without any reduction of ER- $\alpha 66$ mRNA [68-70]. However, it was reported that ICI182,780 failed to induce degradation of ER- $\alpha 36$ [71], probably due to truncated ligand-binding domain of ER- $\alpha 36$ which lacked the helices 9-12 of ER- $\alpha 66$ [6]. The helix-12 domain is critical in protein degradation induced by ICI182,780, different positioning of helix 12 and $F$ domain of ER- $\alpha 66$ could regulate various functions between agonists and antagonists [72,73]. It may provide a molecular explanation for the failure of ICI182, 780 to block the non-genomic estrogen signaling mediated by ER- $\alpha 36$ in ER-negative breast cancer [7] (Figure 6C).

The aromatase inhibitors (AIs) like anastrazole and letrozole may deprive estrogen ligands of ER. Aromatases are involved in non-genomic signaling pathway like MAPK/ERK and PI3K/AKt in ER- $\alpha 36$ expressing cells [41]. It was found that anastrozole and letrozole suppressed the plasma level of E2 in breast cancer patients [74]. Breast cancer cells with high expression of ER- $\alpha 36$ can respond to a very low concentration of E2 through the activation expression of ER- $\alpha 36$ is proved to induce estrogen hypersensitivity [41]. Therefore, this could be an explanation for the failure of AIs treatment in ER-negative breast cancer (Figure 6A).

ER-negative tumors are often treated with nonspecific cytotoxic chemotherapeutic agents. Studies revealed that taxane-containing chemotherapy yielded a higher overall pathologic complete response rate in patients with ERnegative tumors than in patients with ER-positive tumors [75]. It was indicated that overexpression of ER- $\alpha 66$ decreased the sensitivity of Bcap37 cells (ER- $\alpha 66$ negative) to paclitaxel, suggesting a possible role of ER in chemosensitivity of breast cancer [76]. Our laboratory investigated the possible influence of ER- $\alpha 36$ on the therapeutic effects of paclitaxel in ER-negative breast cancer cells. We found that ER- $\alpha 36$ depletion by microRNA sensitized MDA-MB-231 cells to paclitaxel and the JNK pathway appeared to be involved in the mechanism. It may be a new alternative option to modify or improve therapeutic sensitivity and resistance of breast cancer by blocking ER$\alpha 36$-mediated non-genomic effects and ER- $\alpha 36$-associated kinase activities.

According to the findings of our lab and others, ER- $\alpha 36$ knockdown resulted in reduced proliferation rate together with decreased in vitro migratory and invasive ability of breast cancer cells regardless of conventional ER (ER- $\alpha 66)$ status. Furthermore, ER- $\alpha 36$ inhibition led to increased chemotherapy sensitivity of ER-negative breast cancer and increased sensitivity to endocrine therapy of ER-positive breast cancer. Thus, targeting strategies against ER- $\alpha 36$ may be a potential treatment for different subtypes of breast cancer (Figure 7).

\section{Endometrial cancer}

ER- $\alpha 36$ is localized in both plasma membrane and cytoplasm of endometrial cancer cell $[17,36,41]$. ER- $\alpha 36-$ mediated activation of MAPK/ERK and PI3K/Akt pathways promotes proliferation of endometrial cancer cells by different ligands including E2, tamoxifen and testosterone $[36,41,44]$. In addition, ER- $\alpha 36$ expression is positively associated with advanced clinical stage, pathological grade and poor disease-free survival (DFS) rate of endometrial 


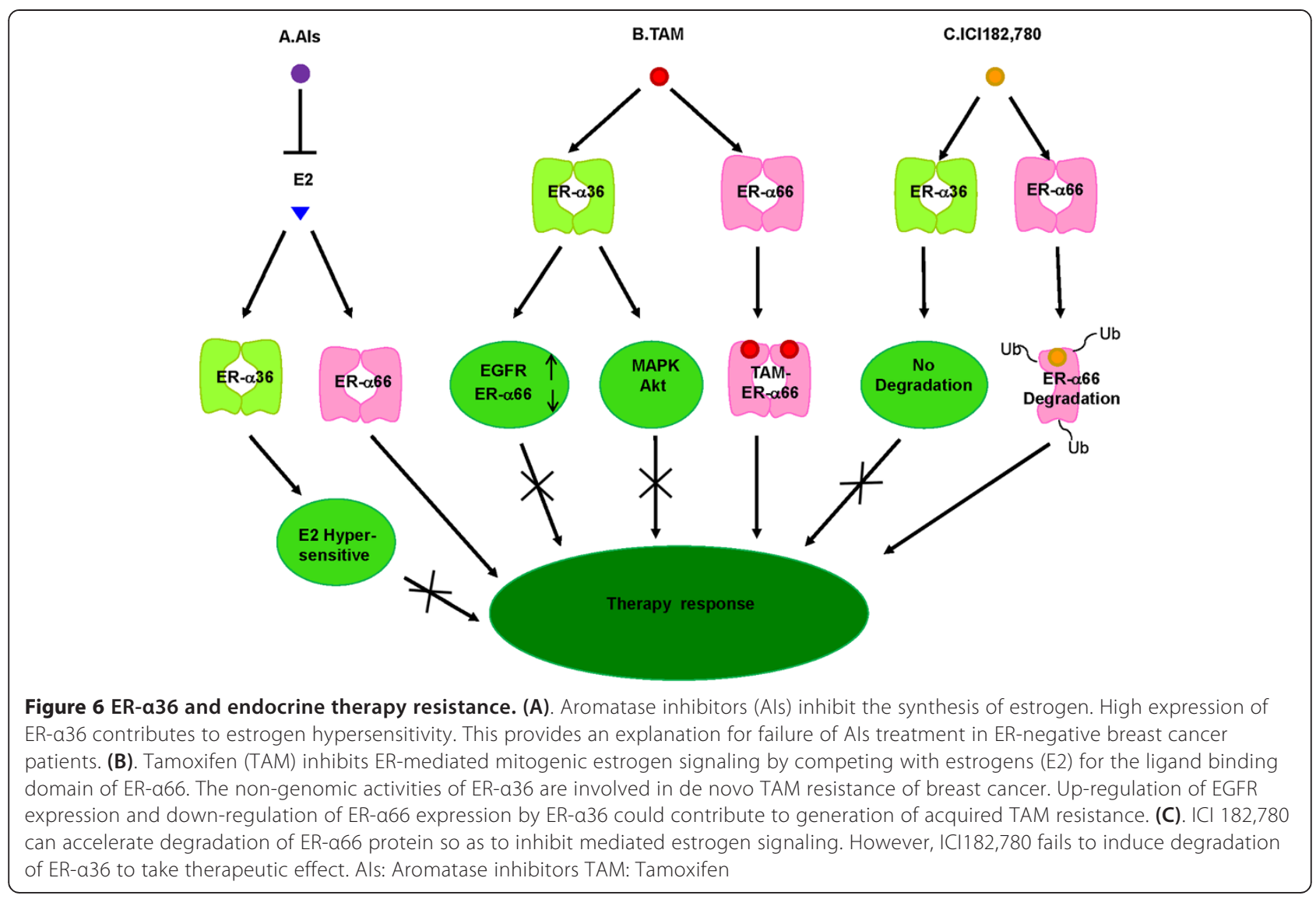

cancer cases [17]. The expression of ER- $\alpha 36$ in endometrial cancer tissues is significantly lower than that in normal and atypical hyperplasia of endometrial tissues [77]. Thus, ER-

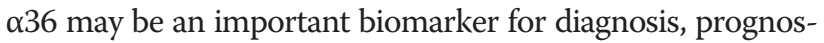
tication and treatment of endometrial carcinoma (Table 1).
It would be even more important if advanced technologies, omics science, systems biology, or clinical bioinformatics, can be applied to investigate dynamic networks and interactions of the ER- $\alpha 36$-specific and dominated elements and understand the molecular mechanisms [78-82].

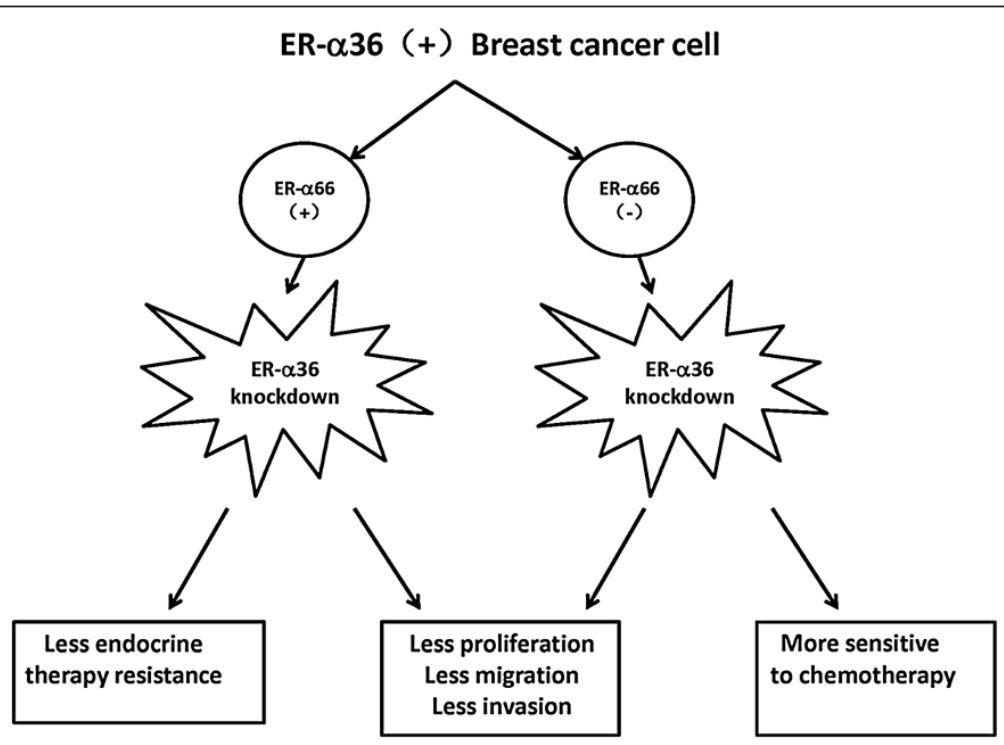

Figure 7 The therapeutic significance of ER- $a 36$ in breast cancer. 


\section{Conclusions}

As a novel isoform of ER- $\alpha 66$, membrane-associated ER- $\alpha 36$ mainly mediates non-genomic effects of ER regulating various physiopathological processes especially in endocrine resistance of estrogen-dependent tumors. ER- $\alpha 36$ inhibits genomic signaling of nuclear ER and mediates the non-genomic estrogen signaling. Increased expression of ER- $\alpha 36$ is associated with decreased expression of ER- $\alpha 66$ in some cancers. Furthermore, ER- $\alpha 36$ is correlated with larger tumor size, more lymphangiogenesis, more distant metastasis, advanced severity of disease, and poor survival of patients with breast cancer. In all, ER-

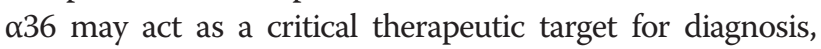
prognostication, and personalized treatment of estrogendependent tumors.

\section{Abbreviations}

ER: Estrogen receptor; E2: Estradiol; MAPK: Mitogen-activated protein kinase; ERK: Extracellular signal-regulated kinases; JNK: c-Jun N-terminal Kinase; PI3K: Phosphatidylinositide 3-kinase; EGFR: Epidermal growth factor receptor; HER2: Human epidermal growth factor receptor 2; STAT: Signal transducer and activator of transcription; SNCG: Synucleiny; Cav-1: Caveolin-1; Hsp90: Heat shock protein 90; TAM: Tamoxifen; Als: Aromatase inhibitors.

\section{Competing interests}

All authors declare that they have no competing interests.

\section{Authors' contributions}

YG and TC performed article search and drafted the manuscript. EL and WW participated in figures and table preparation. XW, JC and LT participated in the design of manuscript organization, manuscript refinement. JC and LT provided administrative support and funded experiments. All authors have contributed and approved the final manuscript.

\section{Acknowledgements}

This article was supported by National Natural Science Foundation of China (30772510, 81301996), The Ph.D. Programs Foundation of Ministry of Education of China (20130101120017), Zhejiang Provincial Natural Science Foundation of China (LQ13H160012), and Medical Science and Technology Project of Department of Health of Zhejiang Provincial Government (2013KYA070). The work was also supported by Shanghai Leading Academic Discipline Project (Project Number: B115), The National Nature Science Foundation of China $(91230204,81270099,81320108001,81270131)$, The Shanghai Committee of Science and Technology (12JC1402200, 12431900207, 11410708600), Zhejiang Provincial Natural Science Foundation (Z2080988), Zhejiang Provincial Science Technology Department Foundation (2010C14011), and Ministry of Education, Academic Special Science and Research Foundation for PhD Education (20130071110043).

\footnotetext{
Author details

${ }^{1}$ Department of Surgical Oncology, The 1st Affiliated Hospital, School of Medicine, Zhejiang University, 79, Qingchun Road, Hangzhou 310003 Zhejiang Province, China. ${ }^{2}$ Department of Thoracic Surgery, The 1st Affiliated Hospital, School of Medicine, Zhejiang University, Hangzhou, Zhejiang Province, China. ${ }^{3}$ Hospital Universitario Niño Jesús, Av. Menéndez Pelayo 65, Madrid 28009, Spain. ${ }^{4}$ Department of Breast Surgery, Lihuili Hospital, School of Medicine, Ningbo University, Ningbo, Zhejiang Province, China.

${ }^{5}$ Department of Respiratory Medicine, The First Hospital of Wenzhou Medical University, Wenzhou, China. ${ }^{6}$ Clinical Research Center, The 2nd Affiliated Hospital, School of Medicine, Zhejiang University, Hangzhou, Zhejiang Province, China.
}

Received: 21 July 2013 Accepted: 18 January 2014

Published: 21 January 2014

\section{References}

1. Shao W, Brown M: Advances in estrogen receptor biology: prospects for improvements in targeted breast cancer therapy. Breast Cancer Res 2004, 6:39-52.

2. Jensen EV, Jacobson HI: Basic guides to the mechanism of estrogen action. Recent Prog Horm Res 1962, 18:387.

3. Kuiper GG, Enmark E, Pelto-Huikko M, Nilsson S, Gustafsson JA: Cloning of a novel receptor expressed in rat prostate and ovary. Proc Natl Acad Sci U S A 1996, 93:5925-5930.

4. Murphy LC, Dotzlaw H, Leygue E, Douglas D, Coutts A, Watson PH: Estrogen receptor variants and mutations. J Steroid Biochem Mol Biol 1997, 62:363-372.

5. Zhang QX, Hilsenbeck SG, Fuqua SA, Borg A: Multiple splicing variants of the estrogen receptor are present in individual human breast tumors. J Steroid Biochem Mol Biol 1996, 59:251-260.

6. Wang Z, Zhang X, Shen P, Loggie BW, Chang Y, Deuel TF: Identification, cloning, and expression of human estrogen receptor-alpha36, a novel variant of human estrogen receptor-alpha66. Biochem Biophys Res Commun 2005, 336:1023-1027.

7. Wang Z, Zhang X, Shen P, Loggie BW, Chang Y, Deuel TF: A variant of estrogen receptor-\{alpha\}, hER-\{alpha\}36: transduction of estrogen- and antiestrogen-dependent membrane-initiated mitogenic signaling. Proc Natl Acad Sci U S A 2006, 103:9063-9068.

8. Pearce ST, Jordan VC: The biological role of estrogen receptors alpha and beta in cancer. Crit Rev Oncol Hematol 2004, 50:3-22.

9. van der Eerden BC, Emons J, Ahmed S, Van Essen HW, Lowik CW, Wit JM, Karperien M: Evidence for genomic and nongenomic actions of estrogen in growth plate regulation in female and male rats at the onset of sexual maturation. J Endocrinol 2002, 175:277-288.

10. Bjornstrom L, Sjoberg M: Mechanisms of estrogen receptor signaling: convergence of genomic and nongenomic actions on target genes. Mol Endocrinol 2005, 19:833-842.

11. Cheskis BJ, Greger JG, Nagpal S, Freedman LP: Signaling by estrogens. J Cell Physiol 2007, 213:610-617.

12. Osborne CK, Schiff R: Estrogen-receptor biology: continuing progress and therapeutic implications. J Clin Oncol 2005, 23:1616-1622.

13. Weihua Z, Andersson S, Cheng G, Simpson ER, Warner M, Gustafsson JA: Update on estrogen signaling. FEBS Lett 2003, 546:17-24.

14. Kong EH, Pike AC, Hubbard RE: Structure and mechanism of the oestrogen receptor. Biochem Soc Trans 2003, 31:56-59.

15. Hall JM, McDonnell DP: The estrogen receptor beta-isoform (ERbeta) of the human estrogen receptor modulates ERalpha transcriptional activity and is a key regulator of the cellular response to estrogens and antiestrogens. Endocrinology 1999, 140:5566-5578.

16. Lee LM, Cao J, Deng H, Chen P, Gatalica Z, Wang ZY: ER-alpha36, a novel variant of ER-alpha, is expressed in ER-positive and -negative human breast carcinomas. Anticancer Res 2008, 28:479-483.

17. Tu BB, Lin SL, Yan LY, Wang ZY, Sun QY, Qiao J: ER-alpha36, a novel variant of estrogen receptor alpha, is involved in EGFR-related carcinogenesis in endometrial cancer. Am J Obstet Gynecol 2011, 205(227):e221-e226.

18. Jiang $H$, Teng $R$, Wang $Q$, Zhang $X$, Wang $H$, Wang Z, Cao J, Teng L: Transcriptional analysis of estrogen receptor alpha variant mRNAs in colorectal cancers and their matched normal colorectal tissues. J Steroid Biochem Mol Biol 2008, 112:20-24.

19. Wang J, Li J, Fang R, Xie S, Wang L, Xu C: Expression of ERalpha36 in gastric cancer samples and their matched normal tissues. Oncol Lett 2012, 3:172-175.

20. Miceli V, Cocciadiferro L, Fregapane M, Zarcone M, Montalto G, Polito LM, Agostara B, Granata OM, Carruba G: Expression of wild-type and variant estrogen receptor alpha in liver carcinogenesis and tumor progression. OMICS 2011, 15:313-317.

21. Chakraborty P, Roy SK: Expression of estrogen receptor alpha 36 (ESR36) in the hamster ovary throughout the estrous cycle: effects of gonadotropins. PLoS One 2013, 8:e58291.

22. Acconcia F, Ascenzi P, Bocedi A, Spisni E, Tomasi V, Trentalance A, Visca P, Marino M: Palmitoylation-dependent estrogen receptor alpha membrane localization: regulation by 17beta-estradiol. Mol Biol Cell 2005, 16:231-237.

23. Baulieu EE, Binart N, Cadepond F, Catelli MG, Chambraud B, Garnier J, GasC JM, Groyer-Schweizer G, Oblin ME, Radanyi C, et al: Receptor-associated nuclear proteins and steroid/antisteroid action. Ann N Y Acad Sci 1990, 595:300-315. 
24. Kato S, Endoh H, Masuhiro Y, Kitamoto T, Uchiyama S, Sasaki H, Masushige S, Gotoh Y, Nishida E, Kawashima H, et al: Activation of the estrogen receptor through phosphorylation by mitogen-activated protein kinase. Science 1995, 270:1491-1494.

25. Aronica SM, Kraus WL, Katzenellenbogen BS: Estrogen action via the CAMP signaling pathway: stimulation of adenylate cyclase and CAMP-regulated gene transcription. Proc Natl Acad Sci U S A 1994, 91:8517-8521.

26. Zou Y, Ding L, Coleman M, Wang Z: Estrogen receptor-alpha (ER-alpha) suppresses expression of its variant ER-alpha 36. FEBS Lett 2009, 583:1368-1374.

27. Kang $L$, Wang $L$, Wang $Z Y$ : Opposite regulation of estrogen receptor-alpha and its variant ER-alpha36 by the Wilms' tumor suppressor WT1. Oncol Lett 2011, 2:337-341.

28. Carmeci C, Thompson DA, Ring HZ, Francke $U$, Weigel RJ: Identification of a gene (GPR30) with homology to the G-protein-coupled receptor superfamily associated with estrogen receptor expression in breast cancer. Genomics 1997, 45:607-617.

29. Filardo E, Quinn J, Pang Y, Graeber C, Shaw S, Dong J, Thomas P: Activation of the novel estrogen receptor G protein-coupled receptor 30 (GPR30) at the plasma membrane. Endocrinology 2007, 148:3236-3245.

30. Revankar CM, Cimino DF, Sklar LA, Arterburn JB, Prossnitz ER: A transmembrane intracellular estrogen receptor mediates rapid cell signaling. Science 2005, 307:1625-1630.

31. Kang L, Zhang $X$, Xie Y, Tu Y, Wang D, Liu Z, Wang ZY: Involvement of estrogen receptor variant ER-alpha36, not GPR30, in nongenomic estrogen signaling. Mol Endocrinol 2010, 24:709-721.

32. Wallacides A, Chesnel A, Ajj H, Chillet M, Flament S, Dumond H: Estrogens promote proliferation of the seminoma-like TCam-2 cell line through a GPER-dependent ERalpha36 induction. Mol Cell Endocrinol 2012, 350:61-71.

33. Vranic S, Gatalica Z, Deng H, Frkovic-Grazio S, Lee LM, Gurjeva O, Wang ZY: ER-alpha36, a novel isoform of ER-alpha66, is commonly over-expressed in apocrine and adenoid cystic carcinomas of the breast. J Clin Pathol 2011, 64:54-57.

34. Zhang XT, Kang LG, Ding L, Vranic S, Gatalica Z, Wang ZY: A positive feedback loop of ER-alpha36/EGFR promotes malignant growth of ER-negative breast cancer cells. Oncogene 2011, 30:770-780.

35. Zhang XT, Ding L, Kang LG, Wang ZY: Involvement of ER-alpha36, Src, EGFR and STAT5 in the biphasic estrogen signaling of ER-negative breast cancer cells. Oncol Rep 2012, 27:2057-2065.

36. Lin SL, Yan LY, Zhang XT, Yuan J, Li M, Qiao J, Wang ZY, Sun QY: ER-alpha36, a variant of ER-alpha, promotes tamoxifen agonist action in endometrial cancer cells via the MAPK/ERK and PI3K/Akt pathways. PLoS One 2010, 5:e9013.

37. Li G, Zhang J, Jin K, He K, Zheng Y, Xu X, Wang H, Wang H, Li Z, Yu X: Estrogen receptor-a36 is involved in development of acquired tamoxifen resistance via regulating the growth status switch in breast cancer cells. Mol Oncol 2013, 7:611-624

38. Shi L, Dong B, Li Z, Lu Y, Ouyang T, Li J, Wang T, Fan Z, Fan T, Lin B, et al: Expression of ER-\{alpha\}36, a novel variant of estrogen receptor \{alpha\}, and resistance to tamoxifen treatment in breast cancer. J Clin Oncol 2009, 27:3423-3429.

39. Kang L, Guo Y, Zhang X, Meng J, Wang ZY: A positive cross-regulation of HER2 and ER-alpha36 controls ALDH1 positive breast cancer cells. J Steroid Biochem Mol Biol 2011, 127:262-268.

40. Dufourny B, Alblas J, Van Teeffelen HA, Van Schaik FM, van der Burg B, Steenbergh PH, Sussenbach JS: Mitogenic signaling of insulin-like growth factor I in MCF-7 human breast cancer cells requires phosphatidylinositol 3-kinase and is independent of mitogen-activated protein kinase. J Biol Chem 1997, 272:31163-31171.

41. Lin SL, Yan LY, Liang XW, Wang ZB, Wang ZY, Qiao J, Schatten H, Sun QY: A novel variant of ER-alpha, ER-alpha36 mediates testosterone-stimulated ERK and Akt activation in endometrial cancer Hec1A cells. Reprod Biol Endocrinol 2009, 7:102.

42. Ohshiro K, Schwartz AM, Levine PH, Kumar R: Alternate estrogen receptors promote invasion of inflammatory breast cancer cells via non-genomic signaling. PLoS One 2012, 7:e30725.

43. McMillan J, Fatehi-Sedeh S, Sylvia VL, Bingham V, Zhong M, Boyan BD, Schwartz Z: Sex-specific regulation of growth plate chondrocytes by estrogen is via multiple MAP kinase signaling pathways. Biochim Biophys Acta 2006, 1763:381-392.
44. Tong JS, Zhang QH, Wang ZB, Li S, Yang CR, Fu XQ, Hou Y, Wang ZY, Sheng J, Sun QY: ER-alpha36, a novel variant of ER-alpha, mediates estrogen-stimulated proliferation of endometrial carcinoma cells via the PKCdelta/ERK pathway. PLoS One 2010, 5:e15408.

45. Chaudhri RA, Olivares-Navarrete R, Cuenca N, Hadadi A, Boyan BD, Schwartz $Z$ : Membrane estrogen signaling enhances tumorigenesis and metastatic potential of breast cancer cells via estrogen receptor-alpha36 (ERalpha36). J Biol Chem 2012, 287:7169-7181.

46. Wagner EF, Nebreda AR: Signal integration by JNK and p38 MAPK pathways in cancer development. Nat Rev Cancer 2009, 9:537-549.

47. Zhang J, Li G, Li Z, Yu X, Zheng Y, Jin K, Wang H, Gong Y, Sun X, Teng X, et al: Estrogen-independent effects of ER-alpha36 in ER-negative breast cancer. Steroids 2012, 77:666-673.

48. Horwitz SB: Taxol (paclitaxel): mechanisms of action. Ann Oncol 1994, 5(Suppl 6):S3-S6.

49. Jordan NJ, Gee JM, Barrow D, Wakeling AE, Nicholson RI: Increased constitutive activity of PKB/Akt in tamoxifen resistant breast cancer MCF-7 cells. Breast Cancer Res Treat 2004, 87:167-180.

50. Graf GA, Matveev SV, Smart EJ: Class B scavenger receptors, caveolae and cholesterol homeostasis. Trends Cardiovasc Med 1999, 9:221-225.

51. Lee SW, Reimer CL, Oh P, Campbell DB, Schnitzer JE: Tumor cell growth inhibition by caveolin re-expression in human breast cancer cells. Oncogene 1998, 16:1391-1397.

52. Sloan EK, Stanley KL, Anderson RL: Caveolin-1 inhibits breast cancer growth and metastasis. Oncogene 2004, 23:7893-7897.

53. Wang D, Huang P, Zhu B, Sun L, Huang Q, Wang J: Induction of estrogen receptor $a-36$ expression by bone morphogenetic protein 2 in breast cancer cell lines. Mol Med Rep 2012, 6:591-596.

54. Poola I, Koduri S, Chatra S, Clarke R: Identification of twenty alternatively spliced estrogen receptor alpha mRNAs in breast cancer cell lines and tumors using splice targeted primer approach. J Steroid Biochem Mol Biol 2000, 72:249-258

55. Gotteland M, Desauty G, Delarue JC, Liu L, May E: Human estrogen receptor messenger RNA variants in both normal and tumor breast tissues. Mol Cell Endocrinol 1995, 112:1-13.

56. Pfeffer U, Fecarotta E, Vidali G: Coexpression of multiple estrogen receptor variant messenger RNAs in normal and neoplastic breast tissues and in MCF-7 cells. Cancer Res 1995, 55:2158-2165.

57. Leygue E, Huang A, Murphy LC, Watson PH: Prevalence of estrogen receptor variant messenger RNAs in human breast cancer. Cancer Res 1996, 56:4324-4327.

58. Pelekanou V, Notas G, Kampa M, Tsentelierou E, Radojicic J, Leclercq G, Castanas E, Stathopoulos EN: ERa36, a new variant of the ERa is expressed in triple negative breast carcinomas and has a specific transcriptomic signature in breast cancer cell lines. Steroids 2012, 77:928-934.

59. Zheng Y, Zhang J, Xu ZZ, Sheng JM, Zhang XC, Wang HH, Teng XD, Liu XJ Cao J, Teng LS: Quantitative profiles of the mRNAs of ER-alpha and its novel variant ER-alpha36 in breast cancers and matched normal tissues. J Zhejiang Univ Sci B 2010, 11:144-150.

60. Sun L, Wang J, Zhang L, Li X, Shen D: Expression of ER-a36, a novel variant of estrogen receptor in endometrial carcinoma and its clinical significance. Gynecol Obstet Invest 2013, 75:68-72.

61. Deng $H$, Huang $X$, Fan J, Wang L, Xia Q, Yang X, Wang Z, Liu L: A variant of estrogen receptor-alpha, ER-alpha36 is expressed in human gastric cancer and is highly correlated with lymph node metastasis. Oncol Rep. 2010, 24:171-6.

62. Zhang CC, Shapiro DJ: Activation of the p38 mitogen-activated protein kinase pathway by estrogen or by 4-hydroxytamoxifen is coupled to estrogen receptor-induced apoptosis. J Biol Chem 2000, 275:479-486.

63. Gu Q, Korach KS, Moss RL: Rapid action of 17beta-estradiol on kainate-induced currents in hippocampal neurons lacking intracellular estrogen receptors. Endocrinology 1999, 140:660-666.

64. Dutertre M, Smith CL: Molecular mechanisms of selective estrogen receptor modulator (SERM) action. J Pharmacol Exp Ther 2000, 295:431-437.

65. Zhao Y, Deng C, Lu W, Xiao J, Ma D, Guo M, Recker RR, Gatalica Z, Wang Z, Xiao GG: let-7 microRNAs induce tamoxifen sensitivity by downregulation of estrogen receptor alpha signaling in breast cancer. Mol Med 2011, 17:1233-1241.

66. Slamon DJ, Godolphin W, Jones LA, Holt JA, Wong SG, Keith DE, Levin WJ, Stuart SG, Udove J, Ullrich A, et al: Studies of the HER-2/neu proto-oncogene in human breast and ovarian cancer. Science 1989, 244:707-712. 
67. Dowsett M: Overexpression of HER-2 as a resistance mechanism to hormonal therapy for breast cancer. Endocr Relat Cancer 2001, 8:191-195.

68. Fawell SE, White R, Hoare S, Sydenham M, Page M, Parker MG: Inhibition of estrogen receptor-DNA binding by the "pure" antiestrogen ICI 164,384 appears to be mediated by impaired receptor dimerization. Proc Natl Acad Sci U S A 1990, 87:6883-6887.

69. Dauvois S, Danielian PS, White R, Parker MG: Antiestrogen ICI 164,384 reduces cellular estrogen receptor content by increasing its turnover. Proc Natl Acad Sci U S A 1992, 89:4037-4041.

70. Nicholson RI, Gee JM, Manning DL, Wakeling AE, Montano MM, Katzenellenbogen BS: Responses to pure antiestrogens (ICI 164384, IC 182780) in estrogen-sensitive and -resistant experimental and clinical breast cancer. Ann N Y Acad Sci 1995, 761:148-163.

71. Kang L, Wang ZY: Breast cancer cell growth inhibition by phenethyl isothiocyanate is associated with down-regulation of oestrogen receptor-alpha36. J Cell Mol Med 2010, 14:1485-1493.

72. Mahfoudi A, Roulet E, Dauvois S, Parker MG, Wahli W: Specific mutations in the estrogen receptor change the properties of antiestrogens to full agonists. Proc Natl Acad Sci U S A 1995, 92:4206-4210.

73. Pearce ST, Liu H, Jordan VC: Modulation of estrogen receptor alpha function and stability by tamoxifen and a critical amino acid (Asp-538) in helix 12. J Biol Chem 2003, 278:7630-7638.

74. Geisler J, Haynes B, Anker G, Dowsett M, Lonning PE: Influence of letrozole and anastrozole on total body aromatization and plasma estrogen levels in postmenopausal breast cancer patients evaluated in a randomized, cross-over study. J Clin Oncol 2002, 20:751-757.

75. Zambetti M, Mansutti M, Gomez P, Lluch A, Dittrich C, Zamagni C, Ciruelos E, Pavesi L, Semiglazov V, De Benedictis E, et al: Pathological complete response rates following different neoadjuvant chemotherapy regimens for operable breast cancer according to ER status, in two parallel, randomized phase II trials with an adaptive study design (ECTO II). Breast Cancer Res Treat 2012, 132:843-851.

76. Sui M, Huang Y, Park BH, Davidson NE, Fan W: Estrogen receptor alpha mediates breast cancer cell resistance to paclitaxel through inhibition of apoptotic cell death. Cancer Res 2007, 67:5337-5344.

77. Sun L, Wang J, Zhang L, Li X, Shen D: Expression of ER-a36, a novel variant of estrogen receptor in endometrial carcinoma and its clinical significance. Gynecol Obstet Invest 2012, 75:68-72.

78. Baumgartner C, OsI M, Netzer M, Baumgartner D: Bioinformatic-driven search for metabolic biomarkers in disease. J Clin Bioinforma 2011, 1:2.

79. Wang XD, Liotta L: Clinical bioinformatics: a new emerging science. J Clin Bioinforma 2011, 1:1.

80. Wang XD, Peer D, Petersen B: Molecular and cellular therapies: new challenges and opportunities. Mol Cell Therapies 2013, 1:1.

81. Wang XD, Marincola FM: A decade plus of translation: what do we understand? Clin Transl Med 2012, 1:3.

82. Abraham E, Marincola FM, Chen ZN, Wang XD: Clinical and translational medicine: integrative and practical science. Clin Transl Med 2012, 1:1.

doi:10.1186/1479-5876-12-16

Cite this article as: Gu et al:: The therapeutic target of estrogen receptor-alpha36 in estrogen-dependent tumors. Journal of Translational Medicine 2014 12:16.

\section{Submit your next manuscript to BioMed Central and take full advantage of:}

- Convenient online submission

- Thorough peer review

- No space constraints or color figure charges

- Immediate publication on acceptance

- Inclusion in PubMed, CAS, Scopus and Google Scholar

- Research which is freely available for redistribution 